\title{
Motivating Students in the EFL Classroom: A Case Study of Perspectives
}

\author{
Rima Bahous \\ Department of Education, Lebanese American University \\ Chouran Beirut 11022801 \\ P.O. Box 13 - 5053, Lebanon \\ Tel: 961-186-7099 E-mail: rbahous@lau.edu.lb \\ Nahla Nola Bacha (Corresponding author) \\ Department of Humanities \& Social Sciences, Lebanese American University \\ Byblos, P.O.Box 36, Lebanon \\ Tel: 961-954-7254Ｅ-mail: nbacha@lau.edu.lb \\ Mona Nabhani \\ Department of Education, Lebanese American University \\ Chouran Beirut 11022801 \\ P.O. Box 13 - 5053, Lebanon \\ Tel: 961-186-7099Ｅ-mail: mnabhani@lau.edu.lb
}

Received: January 17, 2011 Accepted: March 21, 2011 doi:10.5539/elt.v4n3p33

\begin{abstract}
Motivating EFL students to develop in the target language is quite complex. In many cases, these students face difficulties in learning English and are often demotivated to learn. Research in classroom motivation has found that certain strategies can help these students adopt more positive attitudes and become more motivated in the learning process. This exploratory study investigates the perceptions through interviewing students and surveying teachers' views in an EFL Program of the problems that hinder these students' learning in the English classes related to motivation. Findings show that learners are not motivated to learn English because of an over-focus on writing skills with very little new learning experiences, uninteresting materials, and unclear links between language courses and their majors or future careers. Results also indicate that teachers complain of unmotivated students and pre-structured syllabi leaving little room for communicative methods. Implications are made for the classroom.
\end{abstract}

Keywords: Language learning, Motivation, University EFL students, Lebanon

\section{Introduction}

Motivating students in the English as a foreign language (EFL) classroom is often a complex and difficult task that involves a multiplicity of psycho-sociological and linguistic factors (Dornyei, 1998; 2010a), but most English teachers will attest to the important role motivation plays in the teaching/learning process. While motivation has been defined in many ways (Liuoliene \& Metiuniene, 2006), in this paper it is simply used by the authors to refer to effective strategies that could help the learners develop their English language skills. How to go about this is a long story with many ups and downs shared by many teachers in staff rooms. This paper, quite unique in the view of the authors, attempts to tackle the problem of 'motivation' in the EFL Program at one American affiliated university in Lebanon. This is part of our story. First we give some background of the context and some main related research.

Lebanon is a pluralistic country where multilingualism and multiculturalism prevail (Thonhauser, 2000). Although Arabic, French, and English are the three main languages used in the country (Shaaban, 1997), many more languages are heard and taught in the different educational institutions. The school systems at both the private and the public sectors teach a minimum of three languages. Arabic, the native language, is only taught in Arabic language classes. English or French, depending on the school medium of instruction, is taught as a language and is used to teach all school subjects. Again either English or French is also taught as the third language (Shaaban \& Ghaith, 1999; Thonhauser, 2000). Despite the importance attached to the second/foreign language, when some students reach university, they still face difficulties coping with English for academic purposes. In this paper, we present the recurrent problems students face in these language classrooms. We elicited students and teachers' views of the 
problems that hinder students' progress in discussing engagingly, thinking critically, and writing academically in the target language and then suggest strategies to motivate them to use the target language effectively. This study is innovative as it seeks university students' views on motivation, a topic that is not rigorously studied on L1 Arabic speakers in the Lebanese context and which could be applicable to other similar contexts.

\section{Review of Literature}

\subsection{Motivation and studying in a second language}

Motivation "energizes" human behavior and "gives it direction" (Dornyei, 1998, p. 117) and is a significant dimension in language learning (Gardner, 1985; Gardner et al. 2004; Lightbown \& Spada, 1993). A large spectrum of theories covers the many variables that affect student motivation in the second language (L2) classroom. These are reviewed and drawn upon in examining the views on foreign/ second language learning of learners and the teachers who participated in this study.

Research on L2 motivation (until the early 1990s) was inspired by Gardner (1983; 1985), Clement (1980) and their colleagues. L2 motivation was then seen as influenced by learners' attitudes towards social perceptions of the L2 and its speakers, their interethnic contact and the resulting degree of linguistic self-confidence (Dornyei, 2001a). For example, Gardner $(1985$, p.6) reports that students' attitudes towards a specific language group are bound to influence how successful they will be in incorporating aspects of that language. This is especially true considering that learning a foreign language is different from learning other subjects as language is viewed as part of one's identity. Williams (1994) argues that learning a foreign language involves far more than simply learning skills or a system of rules, or a grammar. According to him, it involves an alteration in self-image, the adoption of new social and cultural behaviors and ways of being and, therefore, has a significant impact on the social nature of the learner.

In addition, research in L2 motivation by Dornyei (1990, 1994, 1997, 1998, 2001a, b) and Williams (1994) revealed a need for a more pragmatic education centered approach, examining classroom reality and identifying and analyzing classroom specific motives. For example, an empirical survey of motivational strategies in language classrooms in Hungary (Dornyei \& Csizer, 1998) resulted in ten commandments for motivating language learners (p. 215): teachers should set a personal behavior example, make sure that the class atmosphere is relaxed and pleasant, present tasks properly to the learners, have good teacher-student relationships, work on increasing learners' self confidence, ensure that language classes are interesting to the students, promote as much as possible learners' autonomy, personalize the learning process, increase learners' goals, and make sure that learners are familiar with the target language culture. The study was replicated on Taiwanese students (Cheng \& Dornyei, 2007), but the results differed due to the different background, tradition, identity and culture of the participants. Cortazzi and Jin (1999) also found that culture and identity are two essential variables in motivating $\mathrm{L} 2$ learners.

Other researchers also argued that L2 involves the development of an L2 identity and incorporating elements from the L2 culture and contains environmental factors, cognitive factors, featured personality, and social dimensions (Dornyei, 1998). Simard and Wong (2004) support this development of second language awareness as it not only improves second language learning, but it also promotes greater cross cultural understanding among the second language learners. Taking this identity theory further and not excluding previous motivation theories, Dornyei (2010b) has recently described this new approach in second language learning as the 'L2 motivational self esteem' which links the learning of the foreign language to one's personal 'core' or identity. This has implications for learning a foreign language in that the learner develops 'self maturity' and thus 'self motivation' in acquiring the target language.

\subsection{Classroom reality and motivation}

The following are some issues related to motivation in the classroom in the context of the present study.

\subsubsection{Clarity of purpose and motivation}

Burden (2004) found that students need to realize that the purpose of using the target language is not for studying purposes only but also for effective communication. Moreover, Dorneyi (1990), Ghaith (2003) and Oxford (1996) found that when learners see practical purposes in learning the language, they are motivated even if the language is not significant in the learner's community.

\subsubsection{Content, teaching methods and motivation}

Motivation is a major concern in improving reading and consequently fostering literacy (Anderson, Hiebert, Scott \&Wilkinson, 1985), but one should follow up on motivation strategies to check whether they help improve students' achievement in the learned language (Dorneyi, 2001a). Using reading texts that students can understand is another motivating factor. Stott (2004) conducted a study on twenty Japanese students taking English classes at a Japanese university to examine whether reading a selection from Japanese literature translated into English would result in 
better recall and comprehension of the text. Findings indicate that some but not all familiar topics and texts enhance motivation and that teachers should expose students to reading texts from other cultures as well. Teachers should evaluate suitability of the reading materials to their learners in both cases.

\subsubsection{Positive learning experiences and motivation}

Research has shown that one's positive experiences and achievement in the foreign language impacts one's confidence in using it. Clement's (1980) model focused on the influence of the social context on one's motivation in second language learning. He found that positive language learning experiences increase learners' self confidence in using the second language and further motivation to learn it. This even applies to contexts that do not provide direct interaction with native speaker communities. Gardner et al. (2004) agree that language learning in the classroom and in language clubs and activities help increase 'knowledge, fluency and familiarity ... with the language' (p. 3) and shape attitudes to language learning and future use. Dornyei (1994) argues that language learners are motivated differently according to their achievement and self-confidence, and that the learning situation provides motives through the language classroom, i.e. course, teacher and group aspects (Clement, Dornyei, \& Noels, 1994; Csizer \& Dornyei, 2005a, b).

\subsubsection{Attitude, anxiety and motivation}

Learner's attitude to the learned language impacts the learner outside the classroom (Schumann, 1978; Dornyei \& Skehan, 2003; Csizer \& Dornyei, 2005a, 2005b). A favorable attitude would motivate learners to reach their learning goals as found by Burden (2004) who studied attitude change of Japanese university students in an English conversation class. Gardner et al. (2004) also argue that affective factors influence language acquisition and achievement. They studied the effects of language instruction on "language attitudes, motivation, and anxiety that take place over the academic year" (p. 7) and used the Attitude Motivation Test Battery (AMTB) to measure variables which are important in the socio-educational model such as motivation intensity, desire to learn French, attitudes to learning French and to French Canadians, and interest in foreign languages. They also evaluated the French teacher and the course, the anxiety in the French class and in using French, and whether learning French is instrumental to the participants. Findings show that students' attitudes are influenced by the teacher and the classroom environment; experiences in different classes varied and had different effects on students' interest in foreign languages. The researchers suggest that educators should introduce specific teacher strategies that would increase student motivation and reduce language anxiety.

\subsubsection{Interactive communicative methods and motivation}

Another significant dimension to language learning is providing learners with opportunities to interact freely and learn from each others' mistakes (Lightbown \& Spada, 1993, Davis, 2003; Ghaith, 2003). A study of Chinese university student opinions of their English language courses and how they perceive their language improvement (Yang \& Lau, 2003) showed complaints about the redundancy though at times they did not mind the repetition. Many argued that some of the skills may be taught on the job in a two week period rather than a whole semester. Findings also suggest that students prefer more communicative approaches in teaching and learning English.

Interactive teaching methods for teaching English as a foreign language to university students improves comprehension and communicative competence as found by Morell (2004) who compares conventional non-interactive methods with minimal student interventions with interactive classes that use entertainment, students' oral presentation and student interventions. Findings indicate that in interactive classes, teachers are aware of their students' needs to understand and improve their communicative competence and of the importance of student involvement. In non-interactive classes, teachers felt pressured by time and course syllabus and commented that more time and preparation would be needed if they are to convert to interactive teaching methods.

Interactive classes are also favored by students' language learning strategies in four colleges of business, basic education, technological and health sciences in Kuwait (El-Dib, 2004). Data were analyzed by the Strategy Inventory of Language Learning (SILL) and findings indicate that students prefer the active naturalistic use of the language, i.e. language as the main communicative means by students from different nationalities.

\subsubsection{Impact of teaching strategies on motivation}

Instruction strategies can also enhance students' engagement or involvement in the learning process. Cooperative group learning (Ghaith, 2003) and the use of technology (Al-Jarf, 2004; Ramachaudran, 2004) shift the focus from teacher controlled classrooms to student centered ones. Udvari-Solner (1996) argues for teaching strategies that extend further than delivering instruction to include content that is relevant to the student's lives; Udvari-Solner, Villa, and Thousand (2005) stipulate corrective feedback as part of teaching strategies and designing a teaching-learning process that can promote meaningful participation for all students within the classroom. 


\subsubsection{Acknowledging learning styles and motivation}

In deciding on content that addresses the interests and needs of diverse students, Gardner's Theory of Multiple Intelligences (Gardner, 1983) may be considered to understand and identify strengths in all students. Students' previous learning and knowledge should also be considered as course content is selected. In cases where all students learn the same content, instructors can require different modes of responding to the content such as a variety of oral and written activities. Thus, students may select from several options such as written reports, debates, power point presentations, graphic presentation of comparisons and contrasts, and persuasive and personal position essays. Dornyei and Skehan (2003) similarly point out the importance of individual differences in second language learning.

Fortini and Fizpatrick (2000) suggest re-designing the curriculum to cater for students' differences and help them make sense of what they encounter in their courses which would maximize learning. This may be achieved by adopting a universal design thus creating and designing products and environments for particular purposes. Rose and Meyer (2002) add that in education, a universal design for learning aims at providing students with multiple ways of representation and facilitating engagement and expression. This improves students' access to curriculum content, process, and product, i.e., what instructors want students to learn and how they learn and demonstrate what they have learned. It follows that students are provided with a variety of materials, of means to engage them in learning and expressing what they have learned (Tomlinson, 1995a, 1995b).

\subsubsection{Impact of writing instruction and feedback}

Another problematic practice is the focus on teaching writing in the language class. Harklau (2002) argues that it is not sufficient for second language learners to 'learn how to write' in the target language but in fact learn the second language through writing. According to her, there should be more emphasis on speaking in the second language rather than on writing. Lavelle and Zuercher (2001) examined university writing approaches and students' views on writing and their experiences as writers. The findings highlight the importance of facilitating writing for university students by including comprehensive tasks, emphasizing revision and meaning, scaffolding learners, modeling, and teaching writing across the curriculum.

McCune (2004) conducted a longitudinal study of first year university students in a Scottish university. She used interviews to examine students' essay writing, how they conceive the process, and whether they benefit from their teachers' feedback. McCune (2004) found that students had difficulty in understanding and following their teachers' feedback and guidance because of their own conceptions of essay writing and handouts, and so their writing was not well developed.

The literature also shows that students face difficulties in changing to more sophisticated essay writing as expected by their teachers (Campbell, Smith, \& Brooker, 1998; Norton, 1990; Prosser \& Webb, 1994). Interviewed students did not understand the nature of essay writing, so they could not benefit from their teacher's advice and handouts. This led to a negative attitude to essay writing. The study shows the importance of the learning context and of providing help for students other than handouts and feedback such as self and peer assessment to help students understand what teachers require of them (Mowl \& Pain, 1995; Oldfield \& McAlpine, 1995). McCune (2004) also suggests individualized help because students' intellectual development is varied and requires "tailored support" and dialogue between teacher and student (p. 279). This helps reduce the effect of negative self-assessment.

The idea that learners' first language interferes with learning a new language was studied by Lightbown and Spada (1993) among others. However, Khuwaileh and Al- Shoumali (2000) examined whether the academic English and Arabic writing ability of L1 Arabic learners at university is the same in their mother tongue and the foreign language. The findings show that there is no correlation between students' writing in the first and foreign language and that the majority of the learners had more serious language mistakes in Arabic than in English.

\subsubsection{Using technology and motivation}

Using technology and activities in teaching language can enhance learning. Al-Jarf (2004) studied the influence of using technology in teaching and learning writing skills for EFL college students in King Saud University, Saudi Arabia. The two groups engaged in the study were exposed to the same traditional class writing instruction based on the textbook. However, students of the experimental group were encouraged to use the Internet and computers to check and improve their class essays at home. Both groups were post-tested. Findings revealed that the experimental group made higher gains in writing achievement, improved in motivation, sense of achievement and self-esteem. Technology had a positive effect on their attitude towards the writing process and made writing an enjoyable task. It encouraged more writing and exchange of ideas outside the classroom. Ramachaudran (2004) adds that using new forms of technologies in the language class will certainly encourage and motivate learners to use the target language. 
Similarly, Kim (2003) found a positive influence of email talk on English speaking skills of elementary and middle school students. The learners' interaction in the English language improved their language proficiency. They were interacting with other learners, teachers and online learning content. Students became more expressive in the computer-based communications than in their classroom environments and demonstrated more active participation. The middle school students improved in vocabulary use and pronunciation on their voice mail messages but not on grammar use. Kim (2003) concludes that email can be a tool for improving written language skills and oral language proficiency.

\subsubsection{Impact of reward on motivation}

In some schools, language teachers use rewards to enhance motivation in language learning as suggested by Schunk (1983). Meyer (1995) argues that motivating students to become active readers requires a national program that rewards reading. Johnson (1995) refers to such programs as "Earning by Learning" (EBL). The program aims to motivate academically low achieving students to read by rewarding them with cash and adult attention. Although educators favor intrinsic motivation, Oldfather (1995) argues for using extrinsic rewards to motivate those who are academically frustrated. Terrel and Rundulic (1996) also argue that rewarding students for completing a task improved self-esteem, which increases motivation. McNinch (1997) applied the EBL program in a summer program at an elementary school in a small American town and provided cash reward. Adult volunteers discussed readings with 20 participant children with academic problems. Findings indicate improvement in self-esteem (84\%), school grades (72\%), reading levels (63\%) and school attitudes (86\%). McNinch (1997) concludes that providing students with environments rich with books, caring adults and rewards can improve reading motivation.

In the above section, we attempted to review some of the available literature on the topic. Most researchers seem to reach the same conclusion. A variety of materials should be available to students to cater for different learning styles, and perhaps differentiated instruction should take place. Courses geared towards teaching the target language across the curriculum should be offered. Classes should be student centered. This can be achieved through cooperative learning and use of technology to name a few ways. Learners have to be motivated to learn and become efficient in the target language. This can be achieved by promoting positive student attitudes towards the language.

\section{Aim}

As mentioned at the beginning of this paper, the aim of the study us to find out the views of the teachers and students of what hinder students' language learning in the English language classroom in discussing engagingly, critical thinking, and academic writing.

The significance of the study is its value to the teachers at the university to improve the teaching/learning situation.

\section{Method}

\subsection{Research context}

The study is conducted in the English language department at a university that follows the American system of education in Beirut. Students take three obligatory language courses in communication and rhetoric skills, and each class meets three times a week for 50 minutes over a fifteen-week semester. The objectives of these classes fluctuate from teaching basic language skills and sub-skills, to paragraph, essay, and research paper writing from informative to argumentative writing, from reading for literal comprehension to critical reading, and finally to oral communication presentations (course syllabi). Learners go through all these language courses, but some are exempted based on their English entrance exam scores. They supposedly learn, hopefully improve, but usually complain about the repetition in objectives and learning outcomes from the remedial to the advanced courses, the essay being the most often repeated assignment. Teachers often complain about the learners' inadequacy in using the language appropriately and efficiently.

The university where this study is conducted caters for a variety of students who come from diverse cultural, educational, linguistic, or social backgrounds. Various dialects and accents of Arabic, French, English, Armenian, Spanish and Portuguese are heard on campus. In this multilingual/multicultural context, there is a great deal of code-switching which is a common trait of the Lebanese culture. Students and teachers code-switch easily from one language to the other unconsciously (see for instance, Thonhauser, 2000).

\subsection{Participants}

\subsubsection{Students}

We chose to interview thirty students attending the different English language courses in the English as Foreign Language (EFL) Program at the University: Semi-structured interviews were conducted individually and face-to-face (see Appendix A, students' interview questions). Coordinators were asked to select six students at random from each 
English course ( 5 courses in all) to be interviewed. The majority of the students who answered are between the ages of 18 and 21. Of the thirty interviewed students, twenty students are majoring in business, three are majoring in graphic design, two in education, two in computer science, one in engineering, one in pharmacy, and one in communication arts.

\subsubsection{Teachers}

We sent email semi-structured questionnaires consisting of four main questions to the English language teachers in the EFL Program at the University (see Appendix B, teachers' email questionnaire). Out of the twenty full-time and part time teachers a $30 \%$ response rate was received. The student and teacher sample was considered adequate for this preliminary study.

\subsection{Procedure and instruments}

The research design is qualitative using mixed methods of questionnaires and semi structured interviews. Our sample is purposive because it serves the objectives of our study to "gain insight" in the selected phenomenon (Fraenkel \& Wallen, 2000, p. 465) which is the perceptions of teachers and students of student motivation during the English language classes. We also kept notes on the general discussions and meetings regarding the English language courses that took place at the university. Furthermore, we recorded informal comments of students and teachers whenever the subject of the English courses was mentioned. Items for interviews and questionnaires were derived from the reviewed literature on motivation in language classes.

Ethical considerations were attended to. We sought approval from the concerned universities body to conduct the study in the English language classes at the university. Once the approval was granted, the data collection tools were prepared, piloted, and adjusted accordingly. The participants were informed of the purpose of the research and that the information obtain will be confidential, anonymous and voluntary. This also helped diminish researchers' bias. Confidentiality was ensured by using fictional names, and integrity was upheld in dealing with participants and data.

Qualitative data analysis was used to find consistent patterns in the various perspectives revealed in the interview data and researchers' notes. Transcripts were read thoroughly and common themes and perceptions were highlighted. The instruments used to collect the data complemented each other. They gave us a clearer picture of the problems students face in the language classes. They also drew on teachers' and students' views regarding the issue at hand. Thus we were able to draw our own conclusion and suggest solutions for such problems. Findings were compared to some international studies.

Validity or the appropriateness of the inferences that are made and reliability or the dependability of the results were ensured by using two types of qualitative data at the time, eliciting the responses and perceptions from the interviews and questionnaires gave meaningful data.

\section{Results}

The results of the student interviews and teacher questionnaires are given according to three thematic issues related to motivation as mentioned below.

\subsection{Purpose of language classes}

Many students believed that the English language classes help them cope better with other courses at the university, but ten denied this. In fact, these ten students did not seem to really know what they needed. What is of concern is that these students believe that the English language courses are mainly set to improve their writing skills since the assignments are mainly writing ones. Critical thinking, reading strategies, listening comprehension, and speaking were not mentioned by the students during the interviews.

Though students complain about their English language courses, the majority agree that such courses should be obligatory; however, seven of those who were interviewed would rather have some of these courses offered as optional ones, and only one student would rather not have English courses at all. In fact, students have reiterated in their comments that they'd rather have fewer English language courses as in many cases there is redundancy.

Teachers stated that their role is to help students cope with and improve their academic writing skills, follow process writing in all its steps; give them enough basic knowledge in the grammatical structure of the target language so that they can write better and choose interesting subjects and/or topics for students. They would rather encourage students to support their writing with resources, to learn how to be well organized, and be able to follow and examine models of different academic genres.

\subsection{Content and teaching methods}

When asked to list the two most important strategies to help students discuss engagingly in the target language, teachers claimed that one of the strategies that may help learners is to create a relaxed atmosphere in the class. They 
also mentioned the following: Teachers should also motivate learners by choosing topics that interest students and not teachers. Setting up a conductive environment with relevant and interesting activities is also very important. Classes should be learner centered and not teacher oriented. Teachers should supply students with enough background information, i.e. reading materials, prior to a discussion so that students can support their arguments properly.

When asked to list the two most important strategies related to think critically in the target language, teachers' answers were as follows: 'to focus on questions about logic, the writer and emotions which will lead to good critical thinking. Let learners give their own opinion/position. Challenge them so that they can persuade their readers appropriately.'

\subsection{Language skills (reading, writing and grammar)}

All teachers agreed that there are some problems that hinder students' progress in the English classroom. The repeated answer was lack of motivation due to different factors. Accordingly, teachers tend to blame the weak background of the students such as they barely know the basics of the English language needed for academic purposes, and they come from a culture that does not read or translate from the Arabic or Spanish language. Another problem is that the materials used in the class are of little interest to the students. In addition, learners know the grammatical rules, but they cannot transfer their knowledge and apply what they know into their writing

On the other hand, the vast majority of the learners stated that in their language classes, the emphasis is first on writing skills while only four chose grammar and three reading comprehension. In fact, when learners were asked what they viewed the objectives of the English classes at the university are, the majority of the students agreed that it is again mainly to improve their writing skills. Some claimed that the objectives are to improve their readings strategies, others critical thinking, speaking skills, and to understand spoken English.

Students, in general, complained that the language teachers did not make the courses interesting; they pointed out that the role of the teachers should be to make the courses meet students' needs and help them improve their language. Students added that there should be less writing in the classes and more reading to help them analyze better and there should be more speaking as oral communication is important especially in the global context.

All in all, many teachers blame the attitude of the students who claim that there is no link between their major at the university and the many English courses they have to take.

\section{Discussion}

Teachers and students seem disappointed with the language classes offered at the university. Learners are unhappy on the whole and find the English courses of no benefit. Motivation, then, seems to be an important point in our role in helping students to learn the language (Lightbown \& Spada, 1993; Dornyei \& Csizer, 1998; Cheng \& Dornyei, 2007; Dornyei, 2006). Students want the classes to integrate all language skills and subskills, but unfortunately the main focus of the courses is on writing academic English as also found by Harklau (2002) who argues for focusing on all language skills. Then what is the importance of teaching academic writing to graduating students who will be seeking a career where their main concern will be to write technical reports, communicate with others efficiently, and present their point of view critically among others. More attention should be given to students' diverse needs (Gardner, 1983; Dornyei \& Skehan, 2003) and to multiple methods of learning to facilitate expression and engagement (Ramachaudran, 2004; Mowl and Pain, 1995). This is not denying the importance of writing but mainly to rethink the program in order to benefit learners.

One way is providing scaffolding to benefit language learners especially in writing (Lavelle \& Zuercher, 2001). It seems that the courses do not take into consideration the background of the students: some come from French or Arabic medium pre-university classes while others from different cultural environments and even different countries. There is a clear need for selecting content that is more relevant to the learners' lives (Stott, 2004; Udvari-Solner, 1996) and also on an international level.

Furthermore, the main problem of some of these learners is the difficulty of expressing themselves in the target language. Thus, teachers should allow different ways of responding to the learned material (Gardner, 1983, 1985). Data from this study also show that the speaking component is nearly non-existent in the language classes. El-Dib (2004), Yang and Lau (2003), and Lightbown and Spada (1993) found that students prefer interactive classes and Davis (2003), Ghaith (2003) and Morell (2004) found that when students interact in class, they learn.

Students also want to see more tangible links between the required language courses and their needs. Language learning should not be for studying purposes only but for effective communication and self-expression (Burden, 2004; Dornyei, 1990; Oxford, 1996). Teachers, on the other hand, are not catering for learners' different learning styles either; whereas, they should engage students by using multiple ways of representation (Rose \& Meyer, 2002). They are only following the syllabus, which leaves little time for communicative methods as Morell (2004) found. Program assessment is vital and although some is on the way, more is needed. 
Thus, teachers should not focus just on language accuracy but take into account whether students are communicating their ideas. This by itself is hindering the progress of the students as teachers are not changing their teaching approach to accommodate students (Cortazzi \& Jin, 1999). Thus any feedback to students should be made clear so as to help students improve (McCune, 2004).

\section{Reflections and implications}

This study has shown that there are issues that need to be addressed in the English language classes at the university. Teachers and students are aware of these and have responded that more emphasis be placed on the other skills as well as writing, incorporate interesting life related materials with a link to their university courses and their later professions. Teachers' complaints imply that students are not motivated and something must be done to create more positive attitudes to learning English as part of the EFL Program.

Importantly, therefore, the university should rethink the English language classes. It should reorganize them with appropriate emphasis on the language skills. Also, at the same time workshops on topics such as multiple intelligences (Gardner, 1985; Gardner et al., 2004), catering for students' learning styles (Cortazzi \& Jin, 1999), differentiating instruction (Tomlinson, 1995a; 1995b); teaching and integrating all language skills; using technology in the language classes (Al-Jarf, 2004; Ramachaudran, 2004); and teaching language across the curriculum (Lavelle \& Zuercher, 2001) would greatly, in the opinion of the authors, instill a positive attitude in the teachers and in so doing motivate the learners who will also have a change of attitude and self (Csizer \& Dornyei, 2005a, b; Dornyei, 2010b; Gardner, 1983, 1985; Gardner et al. 2004).

Thus, teachers may help by involving students in choosing some of the materials for the class, engaging them in setting their own goals for language learning as well as providing activities that allow using the language in and outside the class for practical and relevant academic purposes. If motivating learners includes allowing them to being partially or totally in control of their learning, then it follows that the university's English courses should provide opportunities for students to partake in choice of the content, methods and evaluation that both enhance their learning or achieve program objectives. Consequently, instructors should revisit the English Program to meet students' needs.

Motivating our students to learn the language should be priority (Csizer \& Dornyei, 2005a, b; Dornyei, 1990, 1994, 2001a, b, 2006; Dornyei \& Skehan, 2003) as it is only through sharpening this 'tool' that they can be successful in both their academic and professional lives. This study was conducted on a small group of students in one university in Lebanon, and its results cannot by all means be generalized; however, others in similar situations can benefit from them. Thus, we recommend that more research exploring students' motivation in L2 English language classes at the university level be carried out. Our students as others world wide have proved to be effective in their work in any context. Let us join together, share our stories, and give our students the best opportunities to learn and make a difference.

\section{References}

Al Jarf, R. (2004). The effects of web-based learning on struggling EFL college writers. Foreign Language Annals, 37(1), 49 - 57. doi:10.1111/j.1944-9720.2004.tb02172.x, http://dx.doi.org/ 10.1111/j.1944-9720.2004.tb02172.x

Anderson, R. C., Hiebert, E. H., Scott, J. A., \& Wilkinson, L. A. (1985). Becoming a nation of readers. Washington: The National Institutes of Education.

Burden, P. (2004). An examination of attitude change towards the use of Japanese in a university English 'conversation' class. RELC, 35(1), 21 - 36. doi:10.1177/003368820403500104, http://dx.doi.org/ $10.1177 / 003368820403500104$

Campbell, J., Smith, D. \& Brooker, R. (1998). From conception to performance: how undergraduate students conceptualize and construct essays. Higher Education, 36, 449 - 469. doi:10.1023/A:1003451627898, http://dx.doi.org/ 10.1023/A:1003451627898

Cheng, H.F. \& Dornyei, Z. (2007). The use of motivational strategies in language instruction: The case of EFL teaching in Taiwan. Innovation in Language Learning and Teaching, 1(1), 153 - 174. doi:10.2167/illt048.0, http://dx.doi.org/ 10.2167/illt048.0

Clement, R. (1980). Ethnicity, contact, and communicative competence in a second language. In E. Giles, D. Robinson, \& P.M. Smith (Eds.) Language: Social psychology perspectives (pp. 146 - 154). Oxford: Pergamon.

Clement, R., Dornyei, Z., \& Noels, K.A. (1994). Motivation, self confidence and group cohesion in the foreign language classroom. Language Learning, 44, 417 - 448. doi:10.1111/j.1467-1770.1994.tb01113.x, http://dx.doi.org/10.1111/j.1467-1770.1994.tb01113.x 
Cortazzi, M. \& Jin, L. (1999). Cultural mirrors: materials and methods in the EFL classroom. In E. Hinkel (Ed.) Culture in second language teaching and learning (pp. 196 - 219). Cambridge: Cambridge University Press.

Csizer, K. \& Dornyei, Z. (2005a). The internal structure of language learning motivation and its relationship with language choice and learning effort. The Modern Language Journal, 89, 19 - 36. doi:10.1111/j.0026-7902.2005.00263.x, http://dx.doi.org/ 10.1111/j.0026-7902.2005.00263.x

Csizer, K. \& Dornyei, Z. (2005b). Language learners' motivational profiles and their motivated learning behaviour. Language Learning, 55(4), 613 - 659. doi:10.1111/j.0023-8333.2005.00319.x, http://dx.doi.org/ 10.1111/j.0023-8333.2005.00319.x

Davis, A. (2003). Teachers' and students' beliefs regarding aspects of language learning. Evaluation and Research in Education, 17(4), 207 - 216. doi:10.1080/09500790308668303, http://dx.doi.org/ 10.1080/09500790308668303

Dornyei, Z. (1990). Conceptualizing motivation in foreign language learning. Language Learning, 40, 46 - 78. doi:10.1111/j.1467-1770.1990.tb00954.x, http://dx.doi.org/ 10.1111/j.1467-1770.1990.tb00954.x

Dornyei, Z. (1994). Motivation and motivating in the foreign language learning. Language Learning, 40, 46 - 78.

Dornyei, Z., (2001a). Teaching and researching motivation. Essex: Longman.

Dornyei, Z. (2001b). New themes and approaches in second language motivation research. Annual Review of Applied Linguistics, 21, 43 - 61. doi:10.1017/S0267190501000034, http://dx.doi.org/ 10.1017/S0267190501000034

Dornyei, Z. (2006). Individual differences in second language acquisition. AILA Review,19, 42 - 68. doi:10.1075/aila.19.05dor, http://dx.doi.org/ 10.1075/aila.19.05dor

Dornyei, Z. (2010a). The relationship between language aptitude and language learning motivation: Individual differences from a dynamic systems perspective. In E. Macaro (Ed.) Continuum companion to second language acquisition (pp. 247-267). London: Continuum.

Dornyei, Z. (2010b). Researching motivation: From integrativeness to the ideal L2 self. In S. Hunston \& D. Oakey (Eds.) Introducing applied linguistics: Concepts and skills (pp. 74-83). London: Routledge.

Dornyei, Z. \& Csizer, K. (1998). Ten commandments for motivating language learners: Results of an empirical study. Language Teaching Research, 2(3), 203 - 229. doi:10.1191/136216898668159830, http://dx.doi.org/ $10.1191 / 136216898668159830$

Dornyei, Z. \& Otto, I. (1998). Motivation in action: A process model of L2 motivation. Working Papers In Applied Linguistics 4, $43-69$.

Dornyei, Z. \& Skehan, P. (2003). Individual differences in second language learning. In C. Doughty \& M. Long (Eds.) The handbook of second language acquisition (pp. 589 - 630). Oxford: Blackwell Publishers. doi:10.1002/9780470756492.ch18, http://dx.doi.org/ 10.1002/9780470756492.ch18

El-Dib, M. (2004). Language learning strategies in Kuwait: Links to gender, language level and culture in a hybrid context. Foreign Language Annals, 37 (1), 85 - 95. doi:10.1111/j.1944-9720.2004.tb02176.x, http://dx.doi.org/ 10.1111/j.1944-9720.2004.tb02176.x

Fortini, M. \& Fitzpatrick, M. (2000). The universal design for promoting self-determination. In R. A.Villa \& J. S. Thousand (Eds.) Restructuring for caring and effective education: Piecing the puzzle together ( $2^{\text {nd }}$ ed.) (pp. $575-589$ ). Baltimore: Paul H. Brookes.

Fraenkel, J. R. \& Wallen, N. E. (2006) How to design and evaluate research in education. Boston: McGraw-Hill.

Gardner, H. (1983). Frames of mind: The theory of multiple intelligences. New York: Basic Books.

Gardner, R. C. (1985). Social psychology and second language learning: The role of attitudes and motivation. London: Arnold.

Gardner, R. C. Masgoret, A.M., Tennant, J., \& Mihic, L. (2004). Integrative motivation: Changes during a year-long intermediate level language course. Language Learning, 54(1), 1 - 34. doi:10.1111/j.1467-9922.2004.00247.x, http://dx.doi.org/ 10.1111/j.1467-9922.2004.00247.x

Ghaith, Gh. (2003). The relationship between forms of instruction, achievement and perceptions of classroom climate. Educational Research, 45 (1), 83 - 93. doi:10.1080/0013188032000086145, http://dx.doi.org/ $10.1080 / 0013188032000086145$

Harklau, L. (2002). The role of writing in classroom second language acquisition. Journal of Second Language Writing 11 (4), 329 - 350. doi:10.1016/S1060-3743(02)00091-7, http://dx.doi.org/ 10.1016/S1060-3743(02)00091-7 
Johnson, R.C. (1995). Speaker Gingrich touts reading program's payoff (earning by learning. Education Week 14 February 5

Khuwaileh, A. \& Al-Shoumali, A. (2000). Writing errors: a study of the writing ability of Arab learners of academic English and Arabic at university. Language Culture and Curriculum, 13 (2), $174-183$.

Kim, J. (2003). Using mail talk to improve English speaking skills. English Teaching, 58(4), 349 - 369.

Lavelle, E. \& Zuercher, N. (2001). The writing approaches of university students. Higher Education, 42, 373 - 391. doi:10.1023/A:1017967314724, http://dx.doi.org/ 0.1023/A:1017967314724

Liuoliene, A. \& Metiuniene, R. (2006) Second language learning motivation. Santalka. Filologija Edulologija, 14(2), 93-98.

Lightbown, P.M. \& Spada, N. (1993). How languages are learned. Oxford: Oxford University Press.

McCune, V. (2004). Development of first-year students' conceptions of essay writing. Higher Education, 47, 257 282. doi:10.1023/B:HIGH.0000016419.61481.f9, http://dx.doi.org/ 0.1023/B:HIGH.0000016419.61481.f9

McNinch, G. W. (1997). Earning by learning: changing attitudes and habits in reading. Reading Horizons, 37 (3), 186 $-194$

Meyer, R. (1995). Two bucks a book; Gingrich launches national program (earning by learning). School Library Journal, 41

Morell, T. (2004). Interactive lecture discourse for university EFL students. English for Specific Purposes, 23, 325 338. doi:10.1016/S0889-4906(03)00029-2, http://dx.doi.org/ 10.1016/S0889-4906(03)00029-2

Mowl, G. \& Pain, R. (1995). Using self and peer assessment to improve student's essay writing: A case study from geography. Innovations in Education and Training International, 32, 324 - 335.

Norton, L. S. (1990). Essay writing: what really counts? Higher Education, 19, 125 - 138

Oldfather, P. (1995). Commentary: What's needed to maintain and extend motivation for literacy in the middle grades. Journal of Reading, 38, $420-422$.

Oldfield, K. A. \& McAlpine, J. M. (1995). Peer and self assessment at tertiary level an experiential report. Assessment and Evaluation in Higher Education, 20(10), 125 - 132. doi:10.1080/0260293950200113, http://dx.doi.org/ $10.1080 / 0260293950200113$

Oxford, R. L. (1996). New pathways of language learning motivation. In R. L. Oxford (Ed.) Language learning motivation: Pathways to a new century technical report no. 11 (pp. 1-18). Honolulu: University of Hawaii at Manoa, Second language teaching and curriculum centre.

Prosser, M. \& Webb, C. (1994). Relating the process of undergraduate essay writing to the finished product studies. Higher Education, 19, 125 - 138

Ramachaudran, S. (2004). Integrating new technologies into language teaching: two activites for an EAP classroom. TESL Canada Journal, 22 (1), 79 - 90.

Rose, D. \& Meyer, A. (2002). Teaching every student in the digital age: Universal design for learning. Alexandria, VA: Association for Supervision and Curriculum: Development.

Shaaban, K. (1997). Bilingual education in Lebanon. In J. Cummins \& D. Corson (Eds.) Encyclopaedia of language and education: Bilingual education (vol. 5) (pp. 215 - 259). Dordrecht: Kluwer Academic Publishers.

Shaaban, K. \& Gaith, G. (1999). Lebanon's language-in-education policies: From bilingualism to trilingualism. Language Problems and Language Planning, 23, 1 - 16. doi:10.1075/lplp.23.1.01leb, http://dx.doi.org/ 10.1075/lplp.23.1.01leb

Schuman, J. H. (1978). The acculturation model for second language acquisition. In R. Gingras (Ed.) Second language acquisition and foreign language teaching (pp. 27 - 50). Arlington V.A: Center for Applied Linguistics.

Schunk, D. H. (1983). Reward contingencies and the development of children's skills and self-efficacy. Journal of Educational Psychology, 75, $511 \quad-\quad 518$. doi:10.1037/0022-0663.75.4.511, http://dx.doi.org/ 10.1037/0022-0663.75.4.511

Simard, D. \& Wong, W. (2004). Language awareness and its multiple possibilities for the L2 classroom. Foreign Language Annals, 37 (1), 96 - 110. doi:10.1111/j.1944-9720.2004.tb02177.x, http://dx.doi.org/ 10.1111/j.1944-9720.2004.tb02177.x 
Stott, N. (2004). Familiarity breed contempt: Reading texts from learners' own cultures does not guarantee recall. TESOL Quarterly, 38 (2), 345 - 352. doi:10.2307/3588387, http://dx.doi.org/ 10.2307/3588387

Terrell, S. \& Rendulic, P. (1996). Using computer managed instructional software to increase motivation and achievement in elementary school children. Journal of Research on Computing in Education, 28, 403 - 414.

Thonhauser, I. (2000). Multilingual education in Lebanon: 'Arabinglizi and other challenges of multilingualism. Mediterranean Journal of Educational Studies, 6(1), 49 - 61.

Tomlinson, C.A. (1995a). Deciding to differentiate instruction in middle school: one school's journey. Gifted Child Quarterly, 39 (2), 77 - 78. doi:10.1177/001698629503900204, http://dx.doi.org/ 10.1177/001698629503900204

Tomlinson, C. A. (1995b). How to differentiate instruction in mixed-ability classrooms. Alexandria, VA: Association for Supervision and Curriculum Development.

Udvari-Solner, A. (1996). Examining teaching thinking: constructing a process to design curricular adaptations. Remedial and Special Education, 17(4), 245 - 254. doi:10.1177/074193259601700407, http://dx.doi.org/ $10.1177 / 074193259601700407$

Udvari-Solner, A., Villa, R. A., \& Thousand, J. S. (2005). Access to the general education curriculum for all: The universal design process. In R. A. Villa \& J. S. Thousand (Eds.). Creating an inclusive school ( $2^{\text {nd }}$ ed.) (pp. 134-155). Alexandria: Association for Supervision and Curriculum Development.

Williams, M. (1994). Motivation in foreign and second language learning: An interactive perspective. Educational and Child Psychology, 11, $77-84$.

Yang, A. \& Lau, L. (2003). Student attitudes to the learning of English at secondary and tertiary levels. System, 31, 107 - 123. doi:10.1016/S0346-251X(02)00076-3, http://dx.doi.org/ 10.1016/S0346-251X(02)00076-3

\section{Appendix A}

\section{Students' interview questions}

Which skills are emphasized more in your English classes?

In your opinion, what are the objectives of the English classes at the university?

Should English language classes be obligatory or optional?

Do you like the way the classes are taught?

Do you find the time you spend in the classes to be interesting?

Do English language courses meet your needs regarding the use of the English language?

What are three benefits of the English language courses?

Do you think that the English language classes help you cope better with other courses at the university? If yes, how? What do you like/ dislike about the English language classes?

\section{Appendix B}

\section{Teachers' email questionnaire}

Would you answer the following questions related to the teaching/learning of English language classes at the university?

According to you what are the five most important problems that hinder the students' progress in the language classes? According to you what are the two most important strategies to help learners discuss engagingly in the target language?

According to you what are the two most important strategies to think deeply in the target language?

According to you what are the two most important strategies to write academically in the target language? 